\title{
THE APPLICATION OF GOTHIC ARCHITECTURE ON SANTO LAURENSIUS CHIRCH ALAM SUTRA, SERPONG
}

\author{
${ }^{1}$ Sisilia Hermawati. ${ }^{2}$ Ir. C. Sudianto Aly, MT. ${ }^{3}$ Jonathan Hans Y.S., M.Arch \\ ${ }^{1}$ Student in the Bachelor's (S-1) Study Program in Architecture \\ at Parahyangan Catholic University \\ ${ }^{2}$ Senior lecturer in the Bachelor's (S-1) Study Program in Architecture \\ at Parahyangan Catholic University \\ ${ }^{3}$ Senior lecturer in the Bachelor's (S-1) Study Program in Architecture \\ at Parahyangan Catholic University
}

\begin{abstract}
At a glance, the Church of Saint which Laurensius located in Serpong is like a church built in the past. However, when traced, it turns out this church is a new church that was built in 2007 by applying the Style of Gothic Architecture on the building. The application of elements of gothic architecture is not only visible from the outside of the church, but also on the inside of the church. For that, it will be further investigated about the application of any gothic elements contained in the study object.Gothic architectural elements are divided into several periods based on its development, ranging from Early Gothic, High Gothic, Late Gothic to Gothic Revival or Neo-Gothic. Gothic architectural elements have different characteristics and characters in each period of development. In this research, discussed theories about elements in gothic architecture based on its development. There are 17 elements analyzed in this research. These seventeen elements are summarized into three major sections covering the structural elements, non-structural elements, and spatial arrangements. Analysis of the application of gothic architectural elements to the Church of St. Laurensius begins by describing the elements present in the study object and then compared with the gothic architectural elements of the gothic period described in the second chapter. Based on the results of the analysis, it can be seen that from 17 elements observed, 12 elements of which are adapted from the building elements contained in the period of neo-gothic architecture.
\end{abstract}

Key Words: Gothic, Period, Element, Architecture, Neo-Gothic

\section{PENERAPAN ELEMEN ARSITEKTUR GOTHIC PADA GEREJA SANTO LAURENSIUS DI ALAM SUTERA, SERPONG}

\author{
${ }^{1}$ Sisilia Hermawati. ${ }^{2}$ Ir. C. Sudianto Aly, MT. ${ }^{3}$ Jonathan Hans Y.S., M.Arch \\ ${ }^{1}$ Mahasiswi S1 Program Studi Arsitektur Universitas Katolik Parahyangan. \\ ${ }^{2}$ Dosen Pembimbing S1 Program Studi Arsitektur Universitas Katolik Parahyangan. \\ ${ }^{3}$ Dosen Pembimbing S1 Program Studi Arsitektur Universitas Katolik Parahyangan.
}

\begin{abstract}
Abstrak- Bila dilihat sekilas, Gereja Santo Laurensius yang terletak di Serpong ini seperti gereja yang dibangun pada masa lampau. Namun, ketika ditelusuri, ternyata gereja ini merupakan gereja baru yang dibangun pada tahun 2007 dengan menerapkan Gaya Arsitektur Gothic pada bangunannya. Penerapan elemen arsitektur Gothic tidak hanya terlihat dari bagian luar gereja saja, tapi juga pada bagian dalam gereja. Untuk itu, akan diteliti lebih lanjut tentang penerapan elemen Gothic apa saja yang terdapat di objek studi. Elemen arsitektur Gothic ini terbagi ke dalam beberapa periode berdasarkan perkembangannya, mulai dari Early Gothic, High Gothic, Late Gothic hingga Gothic Revival
\end{abstract}

${ }^{1}$ Corresponding Author: sisiliahermawati@gmail.com 
atau Neo-Gothic. Elemen arsitektur Gothic memiliki ciri dan karakter yang berbeda di setiap periode perkembangannya. Dalam penelitian ini, dibahas teori-teori tentang elemen dalam arsitektur Gothic berdasarkan perkembangannya. Ada 17 unsur yang dianalisa dalam penelitian ini. Ketujuh belas unsur ini dirangkum menjadi tiga bagian besar yang meliputi elemen struktural, elemen non-struktural, serta susunan ruang. Analisa penerapan elemen arsitektur Gothic pada gereja dimulai dengan mendeskripsikan elemen-elemen yang ada pada gereja kemudian dibandingkan dengan elemen arsitektur Gothic pada periode Gothic yang telah dijabarkan pada bab kedua. Berdasarkan hasil analisa, maka dapat ditemukan bahwa 12 unsur diantara 17 unsur yang dianalisa diadaptasi dari elemen bangunan yang terdapat pada periode arsitektur neo-Gothic.

Kata Kunci: Gothic, periode, elemen, arsitektur, Neo-Gothic

\section{PENDAHULUAN}

Arsitektur Gothic identik dengan arsitektur gereja yang dibangun pada masa lampau dimana pada arsitektur Gothic terdapat karakteristik tersendiri yang menjadikannya ciri khas yang berbeda dari gaya arsitektur lainnya. Arsitektur Gothic yang begitu elegan menciptakan kesan sakral tersendiri bagi bangunan yang menggunakan gayanya, terutama bangunan gereja sebagai bangunan peribadatan yang menjunjung tinggi nilai sakralitasnya sebagai tempat peribadahan. Bila dilihat sekilas, Gereja Santo Laurensius terlihat seperti gereja-gereja yang dibangun pada masa lalu karena gaya arsitekturnya yang menyerupai Gereja Katedral yang dibangun sejak tahun 1901. Ternyata, ketika dipelajari lebih lanjut, Gereja Santo Laurensius yang terletak di Serpong ini merupakan gereja baru yang dibangun pada tahun 2007. Gaya arsitektur Gothic ini menjadikannya ciri khas dan ikon tersendiri bagi kawasan perumahan Alam Sutera, Serpong ini dikarenakan kawasan ini merupakan kawasan perumahan dengan gaya modern minimalis. Gaya arsitektur Gothic yang begitu menjadi ciri khas tidak hanya tercermin dari bagian eksteriornya saja. Namun, ketika memasuki bagian dalam gereja, terlihat interior berupa vault pada bagian plafon ruang utama yang menjadi salah satu ciri khas arsitektur Gothic pada jamannya. Selain itu, gaya Gothic ini juga tercermin dari bentuk bangunan, elemen pembentuk ruang serta ornamenornamen yang digunakan, misalnya penggunaan kubah pada bagian dekat altar. Pada bagian depan sisi kiri kanan gereja juga terdapat menara yang juga menjadi salah satu ciri khas dari arsitektur Gothic pada jamannya.

Ketika pada masa ini orang semakin memiliki kebebasan dalam merancang, mengapa Gereja Santo Laurensius justru memilih untuk tetap mempertahankan gaya arsitektur Gothic ini? Karena itu, Gereja Santo Laurensius ini dinilai sangat menarik untuk dipelajari dan ditelusuri lebih dalam. Gaya arsitektur Gothic yang begitu melekat pada Gereja Santo Laurensius Serpong ini mengangkat kembali ekspresi-ekspresi gereja yang dibangun terdahulu. Gereja Katolik sebagai tempat ibadah juga memiliki karakter arsitekturnya tersendiri yang telah diterapkan secara turun temurun dari gereja-gereja yang dibangun pada masa lampau. Berangkat dari gaya arsitekturnya yang menarik untuk dikaji lebih dalam pada masa sekarang, maka Gereja Santo Laurensius Serpong dipilih oleh peneliti sebagai bagian objek yang akan diteliti.

Gereja Santo Laurensius sebagai salah satu gereja yang menggunakan langgam arsitektur Gothic pada masa sekarang memiliki unsur-unsur yang menarik untuk dipelajari. Mulai dari elemen-elemen eksterior hingga penerapan elemen interior, seperti flying buttress. Gereja juga sebagai tempat peribadatan yang memiliki penerapan-penerapan karakteristik gereja secara turun temurun sejak awal mula pembentukan gereja di Eropa. Melalui kajian yang dilakukan akan diketahui elemen Gothic apa saja yang diterapkan pada Gereja Santo Laurensius Serpong ini. 
Berdasarkan hal tersebut, maka dirumuskan pertanyaan penelitian sebagai berikut: Bagaimana penerapan elemen arsitektur Gothic pada Gereja Santo Laurensius Serpong?

\section{KAJIAN TEORI}

\subsection{ELEMEN DALAM \\ ARSITEKTUR GOTHIC \\ BERDASARKAN} PERKEMBANGANNYA

Pembagian elemen dalam arsitektur Gothic berdasarkan periodenya dapat dikelompokan menjadi elemen penyusun ruang yang terdiri dari elemen struktur dan non-struktur serta susunan ruang yang berupa denah ${ }^{2}$.

Berdasarkan, pengelompokan-pengelompokan tersebut dapat dirumuskan sebagai berikut :

Tabel 1. Pembagian Elemen dalam Arsitektur Gothic

\begin{tabular}{|ll|}
\hline \multicolumn{1}{|c|}{ Elemen dalam Arsitektur Gothic } \\
\hline a. & Elemen Struktur : \\
& - Columns and Piers - Kolom \\
& - Walls - Dinding Pemikul \\
& - Roof and Vaults - Atap \\
b. & Elemen Non-Struktur : \\
& - Walls - Dinding Pengisi \\
& - Openings - Bukaan \\
& - Dekorasi : Moulding, Ornaments, Spires, Stained Glass, Sculpture \\
\hline
\end{tabular}

Berikut merupakan rangkuman dari dasar teori elemen Arsitektur Gothic berdasarkan perkembangannya yang akan dijadikan sebagai alat analisis pada bab analisa. Elemen bangunan dibagi ke dalam 17 bagian, mulai dari elemen struktural, non-struktural, hingga susunan ruang.

Tabel 2. Elemen dalam Arsitektur Gothic

\begin{tabular}{|c|c|c|c|c|}
\hline Elemen & Early Gothic & High Gothic \\
\hline $\begin{array}{c}\text { Landasan } \\
\text { Kolom }\end{array}$
\end{tabular}




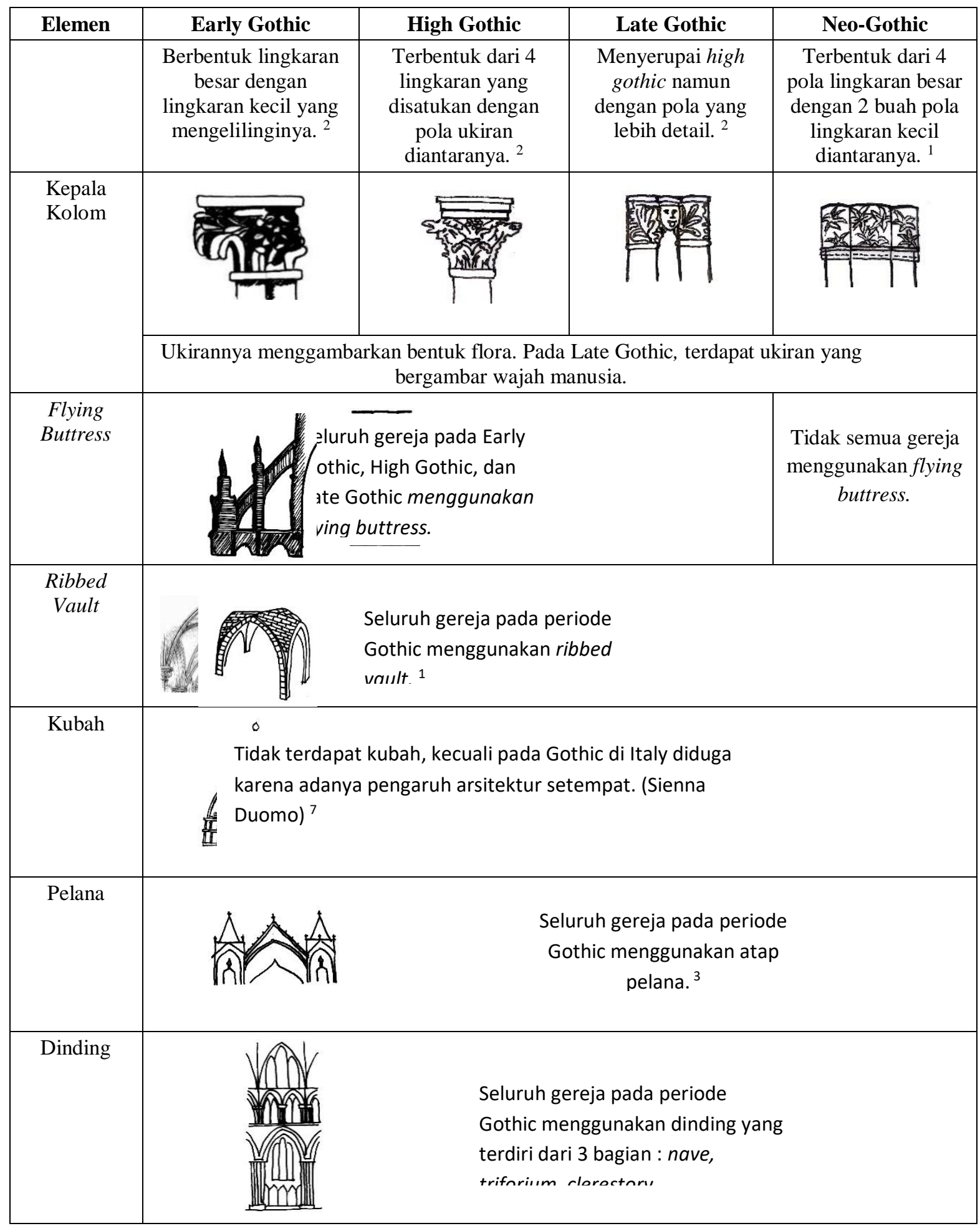




\begin{tabular}{|c|c|c|c|c|}
\hline Elemen & Early Gothic & High Gothic & Late Gothic & Neo-Gothic \\
\hline \multirow[t]{2}{*}{ Pintu } & & & & \\
\hline & $\begin{array}{c}\text { Berbentuk } \\
\text { melengkung di bagian } \\
\text { atasnya. }\end{array}$ & \multicolumn{2}{|c|}{$\begin{array}{l}\text { Berbentuk pointed arch dengan ornamen } \\
\text { ukiran di atasnya. }\end{array}$} & $\begin{array}{l}\text { Berbentuk persegi } \\
\text { panjang dengan } \\
\text { ornamen berbentuk } \\
\text { pointed arch. }{ }^{5}\end{array}$ \\
\hline \multirow[t]{2}{*}{ Jendela } & & & & \\
\hline & $\begin{array}{l}\text { Berbentuk pointed } \\
\text { arch tanpa ornamen } \\
\text { di sekitarnya. }\end{array}$ & $\begin{array}{l}\text { Bentuk lebih variatif } \\
\text { dengan bentuk dasar } \\
\text { pointed arch. }\end{array}$ & $\begin{array}{c}\text { Penggunaan } \\
\text { ornamen yang lebih } \\
\text { detail. }\end{array}$ & $\begin{array}{l}\text { Penggunaan pola } \\
\text { lingkaran pada } \\
\text { bagian atas dengan } \\
2 \text { pointed arch di } \\
\text { bawahnya. }\end{array}$ \\
\hline \multirow[t]{2}{*}{$\begin{array}{l}\text { Rose } \\
\text { Window }\end{array}$} & (5) & 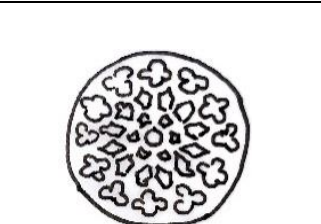 & (3) & 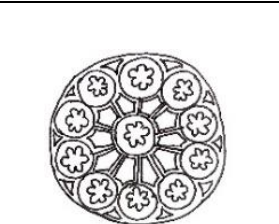 \\
\hline & Belum berpola radial. & Mulai berpola radial. & $\begin{array}{l}\text { Terlihat pembagian } \\
\text { pola radial. }\end{array}$ & $\begin{array}{l}\text { Pola radial sangat } \\
\text { terlihat jelas. }{ }^{5}\end{array}$ \\
\hline \multirow[t]{2}{*}{ Moulding } & & & & \\
\hline & \multicolumn{4}{|c|}{ Tidak terdapat perbedaan yang mencolok, perbedaan terletak pada detail. } \\
\hline $\begin{array}{l}\text { Ornamen } \\
\text { Panel Tracery }\end{array}$ & 1 & & Panel Tracery & \\
\hline Menara & $\stackrel{A}{A}$ & A & & A \\
\hline
\end{tabular}




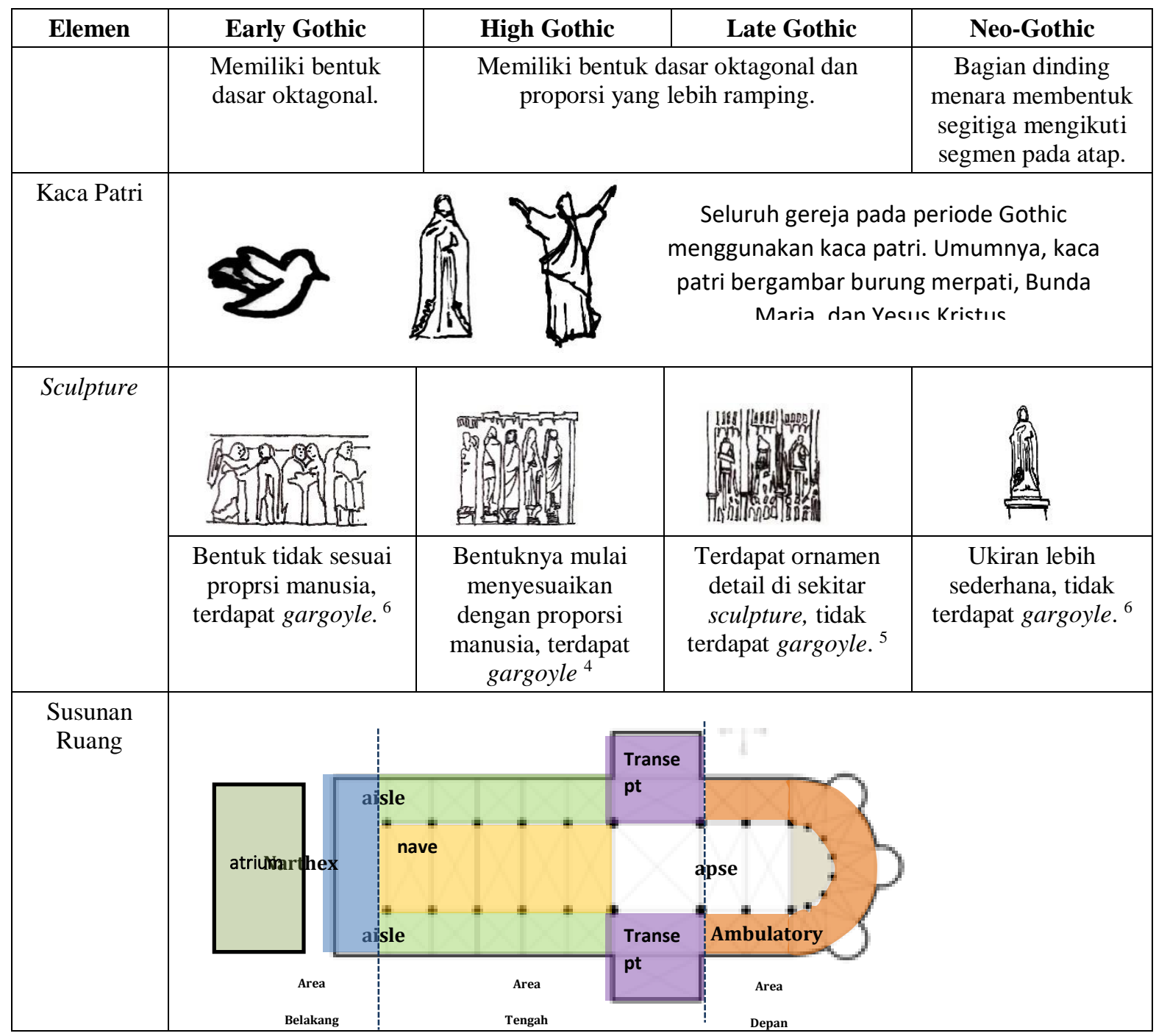

\section{METODA PENELITIAN}

Berdasarkan temuan pada bab II, dasar analisa yang akan digunakan dalam menganalisis penerapan elemen Gothic pada Gereja Santo Laurensius adalah berdasarkan pembagaian elemen pada bangunan yang terdiri elemen struktural, elemen non-struktural, dan susunan ruang.

\section{ANALISA \\ 4.1 GEREJA SANTO LAURENSIUS ALAM SUTERA, SERPONG}




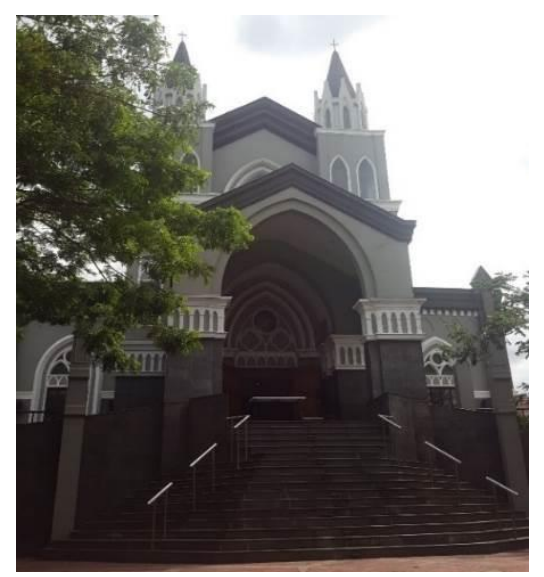

Figur 1. Tampak Gereja Santo Laurensius

Nama awal : Gereja Katolik Alam Sutera

Nama kini : Gereja Santo Laurensius

Lokasi objek : Jl. Sutera Utama No. 2, Alam Sutera, Serpong, Pakulonan Tangerang

Kota Tangerang Selatan

Banten 15326

Tahun didirikan : $2005-2007$

Nama arsitek : Gatot Surarjo

Nama biro arsitek : PT. Arga Calista Disain

Luas lahan : : $10776 \mathrm{~m} 2$

Luas lantai : $2819 \mathrm{~m} 2$

\subsection{ELEMEN STRUKTURAL PADA GEREJA SANTO LAURENSIUS}

Elemen struktural pada objek studi terdiri dari landasan kolom, badan kolom, kepala kolom, balok, serta atap. Berikut analisa elemen struktural pada objek studi berdasarkan pembagian elemen tersebut.

\section{(1) Kolom}

Landasan kolom pada objek studi memiliki bentuk zig-zag dengan bentuk geometri dasar persegi. Landasan kolom ini bermaterialkan beton dengan warna abu-abu tua. Bentuk kolom pada objek studi membentuk kolom berkelompok (clustered column) yang terdiri dari 8 kumpulan kolom yang bersatu menjadi sebuah kolom. Bentuk kolom ini terdiri dari 4 buah pola setengah lingkaran besar yang disisipkan sebuah pola setengah lingkaran kecil diantaranya sehingga membentuk pola selang-seling antara lingkaran besar dan lingkaran kecil. Badan kolom ini bermaterial beton yang diberi finishing cat putih.

Pada bagian kepala kolom, terdiri dari ukiran yang menyerupai ukiran pada landasan kolom. Bentuk ukiran pada kepala kolom ini lebih sederhana dibandingkan dengan ukiran yang terdapat di keempat periode Gothic.

Tabel 3. Kesimpulan Analisa Kolom

\begin{tabular}{|c|c|c|c|c|c|}
\hline Kolom & Objek Studi & $\begin{array}{c}\text { Early } \\
\text { Gothic }\end{array}$ & $\begin{array}{c}\text { High } \\
\text { Gothic }\end{array}$ & $\begin{array}{c}\text { Late } \\
\text { Gothic }\end{array}$ & $\begin{array}{c}\text { Neo- } \\
\text { Gothic }\end{array}$ \\
\hline
\end{tabular}




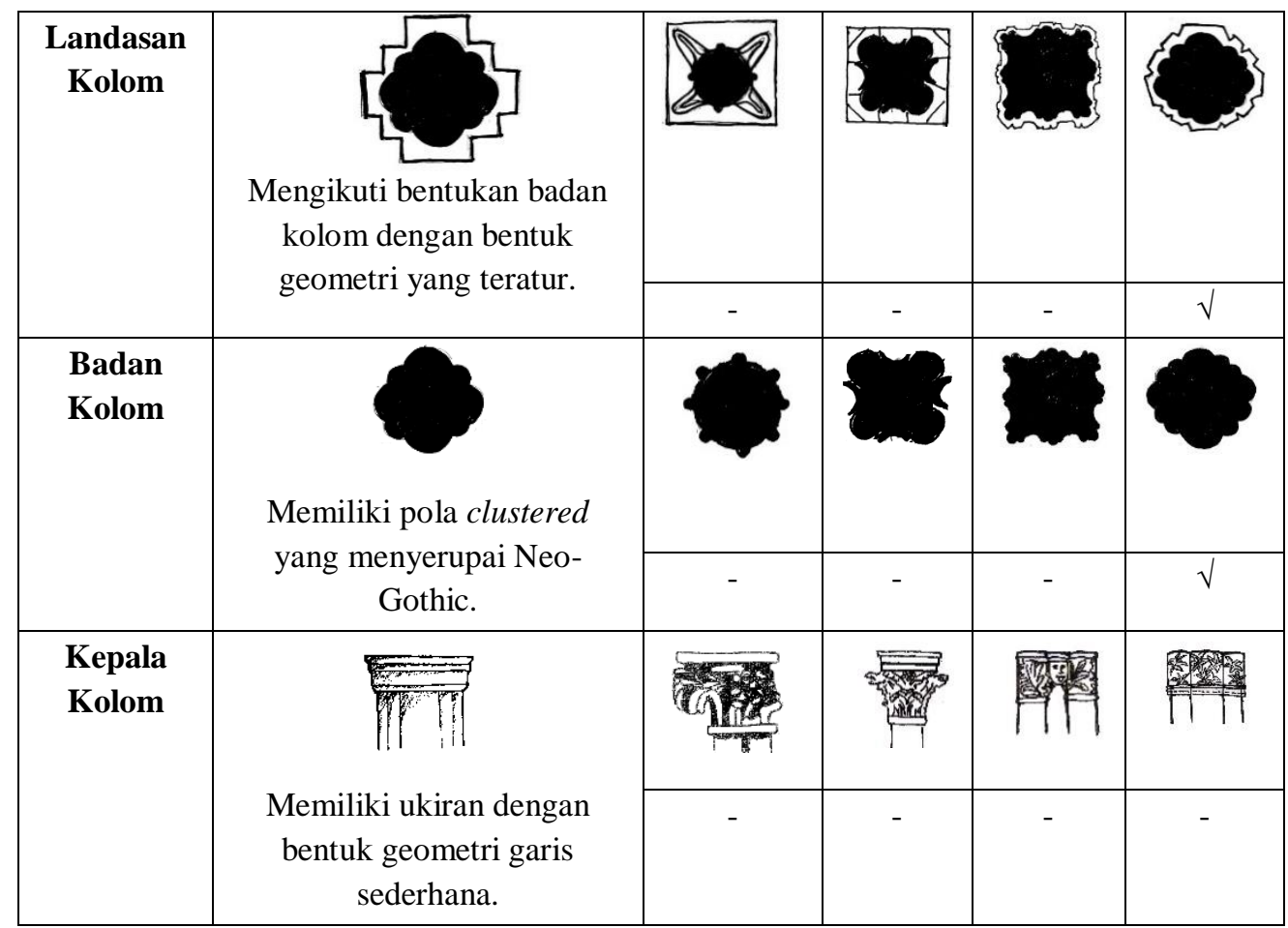

(2)

Dinding Pemikul

Pada objek studi, dinding pemikul terdapat di bagian depan dimana dinding tersebut berfungsi sebagai dinding penahan tanah pada lantai spit level. Pada Arsitektur Gothic, dinding pemikul berupa flying buttress maka dapat disimpulkan objek studi masuk ke periode Neo-Gothic.

Tabel 4. Kesimpulan Analisa Atap

\begin{tabular}{|c|c|c|c|c|c|}
\hline $\begin{array}{c}\text { Dinding } \\
\text { Pemikul }\end{array}$ & Objek Studi & $\begin{array}{c}\text { Early } \\
\text { Gothic }\end{array}$ & $\begin{array}{c}\text { High } \\
\text { Gothic }\end{array}$ & $\begin{array}{c}\text { Late } \\
\text { Gothic }\end{array}$ & $\begin{array}{c}\text { Neo- } \\
\text { Gothic }\end{array}$ \\
\hline \multirow{2}{*}{$\begin{array}{c}\text { Flying } \\
\text { Buttress }\end{array}$} & $\begin{array}{c}\text { Tidak terdapat flying } \\
\text { buttress. }\end{array}$ & \multicolumn{3}{|c|}{ Terdapat flying buttress } & $\begin{array}{c}\text { Ada yang ada } \\
\text { dan ada yang } \\
\text { tidak }\end{array}$ \\
\cline { 3 - 6 } & & - & - & - & $V$ \\
\hline
\end{tabular}

Berdasarkan tabel 4, pada objek studi tidak terdapat flying buttress maka dapat disimpulkan objek studi masuk ke periode Neo-Gothic.

(3) Atap

Atap pada objek studi terdiri dari bentuk vault, kubah, serta pelana.

Tabel 5. Kesimpulan Analisa Atap

\begin{tabular}{|c|c|c|c|c|c|}
\hline Atap & Objek Studi & $\begin{array}{c}\text { Early } \\
\text { Gothic }\end{array}$ & $\begin{array}{c}\text { High } \\
\text { Gothic }\end{array}$ & $\begin{array}{c}\text { Late } \\
\text { Gothic }\end{array}$ & $\begin{array}{c}\text { Neo- } \\
\text { Gothic }\end{array}$ \\
\hline
\end{tabular}




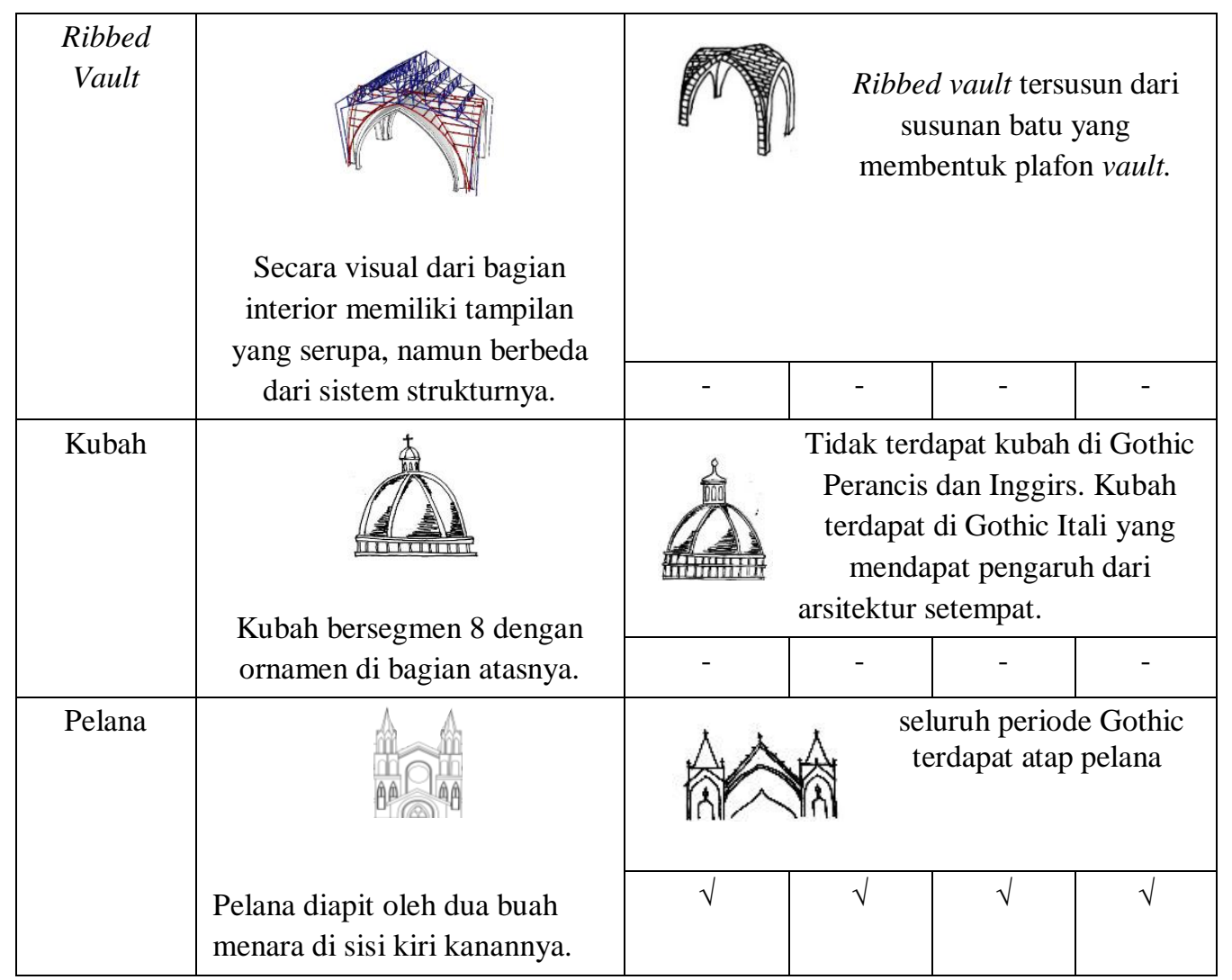

Berdasarkan tabel 5, hanya terdapat 1 dari 3 bagian atap pada objek studi yang menyerupai periode Gothic, yaitu penggunaan atap pelana yang diapit 2 buah menara.

\subsection{ELEMEN STRUKTURAL PADA GEREJA SANTO LAURENSIUS}

Elemen Non-Struktural pada objek studi terdiri dari dinding, bukaan, serta dekorasi. Bukaan terdiri dari pintu dan jendela, sedangkan elemen dekorasi mencakup ukiran, ornamentasi, menara, kaca patri, serta sculpture.

(1) Dinding Pengisi

Pada dinding Gereja Santo Laurensius hanya terdiri dari dua bagian, yaitu bagian bawah dan bagian atas. Bagian atas berhubungan langsung dengan atap dan bagian bawah berhubungan langsung dengan lantai. Pada Arsitektur Gothic, bagian yang berhubungan dengan lantai disebut nave, sedangkan yang berhubungan dengan bagian atap disebut clestory. Pada objek studi tidak terdapat triforium.

Tabel 6. Kesimpulan Analisa Dinding

\begin{tabular}{|c|c|c|c|c|c|}
\hline $\begin{array}{l}\text { Dinding } \\
\text { Pengisi }\end{array}$ & Objek Studi & $\begin{array}{c}\text { Early } \\
\text { Gothic }\end{array}$ & $\begin{array}{l}\text { High } \\
\text { Gothic }\end{array}$ & $\begin{array}{c}\text { Late } \\
\text { Gothic }\end{array}$ & $\begin{array}{c}\text { Neo- } \\
\text { Gothic }\end{array}$ \\
\hline \multirow[t]{2}{*}{ Dinding } & \multirow{2}{*}{$\begin{array}{l}\sqrt{\text { Tidak memiliki }} \\
\sqrt{1} \text { triforium } \\
\end{array}$} & \multicolumn{4}{|c|}{ 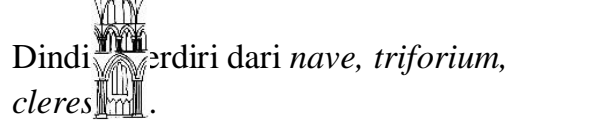 } \\
\hline & & - & - & - & - \\
\hline
\end{tabular}


Berdasarkan tabel 6, dinding pengisi pada objek studi berbeda dengan dinding pada periode Gothic. Selain itu, perbedaan juga terlihat dari proporsi dinding. Dinding pada periode Gothic memiliki ketinggian hampir dua kali lipat dari dinding pada objek studi.

Bukaan

Bukaan pada objek studi terdiri dari pintu dan jendela. Berikut analisa pintu dan jendela yang terdapat pada objek studi.

Tabel 7. Kesimpulan Analisa Bukaan

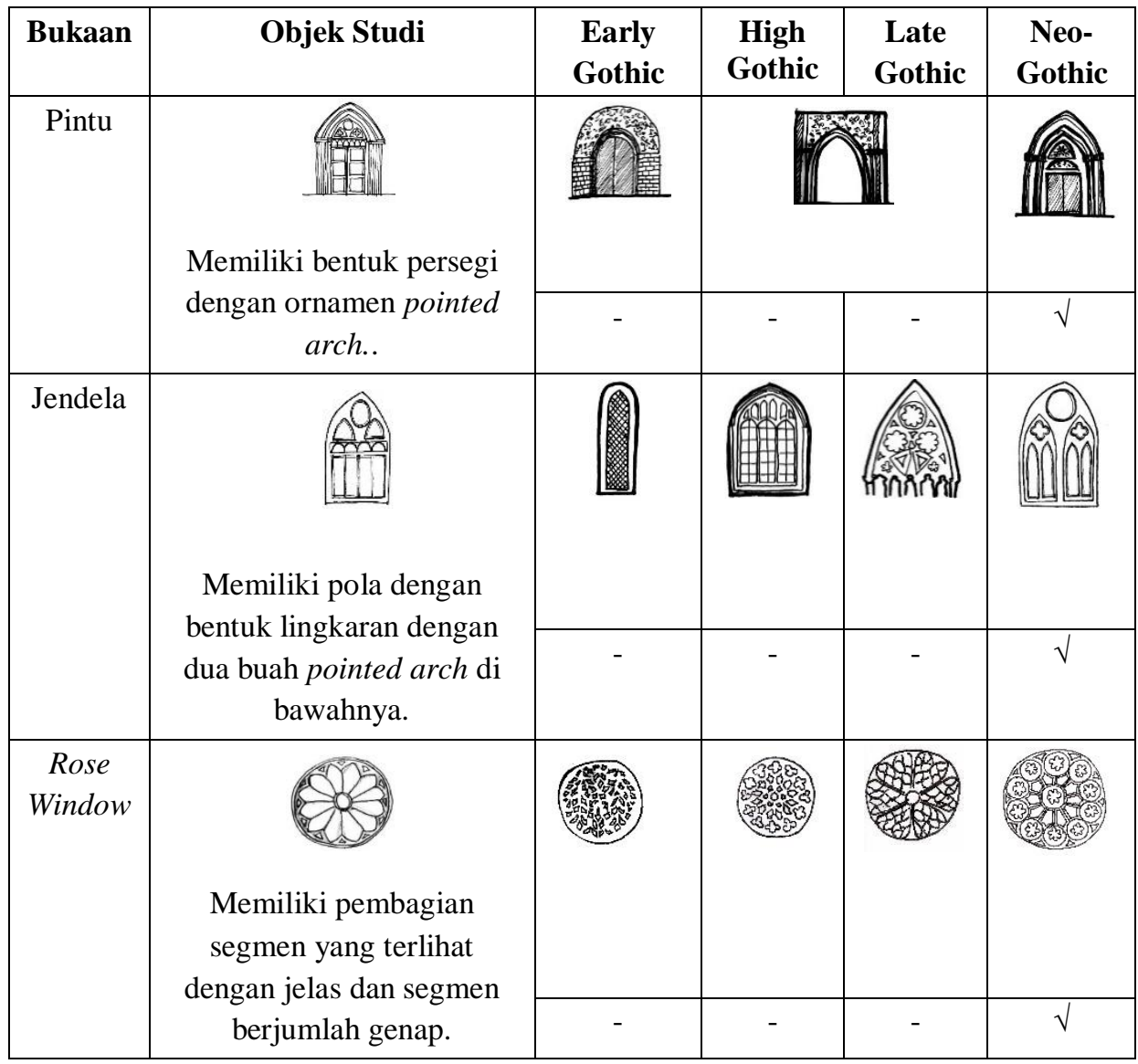

Pada Objek studi, dekorasi terdiri dari ukiran, ornamentasi, menara, kaca patri, sculpture. Berdasarkan tabel 8, elemen dekorasi pada objek studi menyerupai periode Neo-Gothic kecuali pada moulding karena moulding memiliki bentuk yang sangat beragam.

Tabel 8. Kesimpulan Analisa Dekorasi 


\begin{tabular}{|c|c|c|c|c|c|}
\hline Dekorasi & Objek Studi & $\begin{array}{l}\text { Early } \\
\text { Gothic }\end{array}$ & $\begin{array}{l}\text { High } \\
\text { Gothic }\end{array}$ & $\begin{array}{l}\text { Late } \\
\text { Gothic }\end{array}$ & $\begin{array}{l}\text { Neo- } \\
\text { Gothic }\end{array}$ \\
\hline \multirow[t]{2}{*}{$\begin{array}{c}\text { Ukiran } \\
\text { (moulding) }\end{array}$} & \multirow[b]{2}{*}{$\begin{array}{l}\text { terdapat di sekitar jendela, } \\
\text { kolom, pintu. }\end{array}$} & & & & \\
\hline & & - & - & - & - \\
\hline \multirow[t]{2}{*}{$\begin{array}{l}\text { Ornamentasi } \\
\text { (tracery) }\end{array}$} & \multirow[t]{2}{*}{ 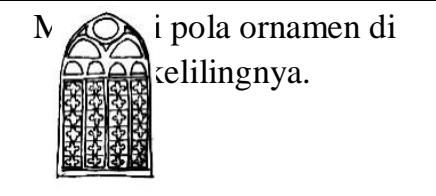 } & \multicolumn{4}{|c|}{$\begin{array}{l}\text { Memiliki kemiripan } \\
\text { dengan geometri tracery }\end{array}$} \\
\hline & & $\sqrt{ }$ & $\sqrt{ }$ & $\sqrt{ }$ & $\sqrt{ }$ \\
\hline \multirow[t]{2}{*}{$\begin{array}{l}\text { Menara } \\
\text { (spire) }\end{array}$} & $\begin{array}{l}\text { ki segmen lancip di } \\
\text { gian ujungnya. }\end{array}$ & N & \multicolumn{2}{|c|}{ : } & 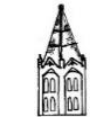 \\
\hline & & - & - & - & $\sqrt{ }$ \\
\hline \multirow[t]{2}{*}{$\begin{array}{c}\text { Kaca Patri } \\
\text { (stained glass) }\end{array}$} & \multirow{2}{*}{$\begin{array}{c}\text { Bergambar Tuhan Yesus, } \\
\text { murid-murid Yesus, Bunda } \\
\text { Maria. }\end{array}$} & \multicolumn{4}{|c|}{$\begin{array}{c}\text { kaca patri bergambar } \\
\text { burung merpati, Bunda } \\
\text { Maria, dan Yesus }\end{array}$} \\
\hline & & $\sqrt{ }$ & $\sqrt{ }$ & $\sqrt{ }$ & $\sqrt{ }$ \\
\hline \multirow[t]{2}{*}{ Sculpture } & \multirow[t]{2}{*}{ 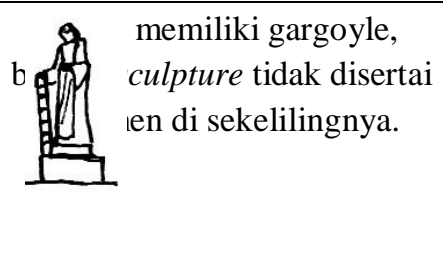 } & 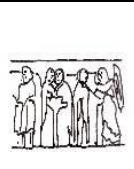 & 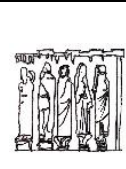 & | lis & 㻟 \\
\hline & & - & - & - & $\sqrt{ }$ \\
\hline
\end{tabular}

\subsection{SUSUNAN RUANG PADA GEREJA SANTO LAURENSIUS}

Bangunan terdiri dari 3 lantai. Lantai pertama merupakan lantai semi-basement. Pada lantai semi-basement tidak ditemukan unsur-unsur Gothic. Lantai semi-basement berupa ruang serba guna yang dibuat dengan tampilan minimalis dan modern. Ruang peribadatan pada objek studi terletak di lantai kedua. Sedangkan lantai atasnya berupa balkon.

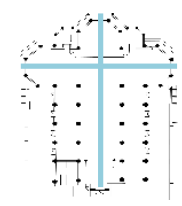

Figur 2. Bentuk denah objek studi

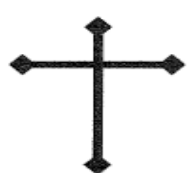

Figur 3.

Bentuk Salib

Latin 
Susunan ruang gereja pada lantai dasar sebagai ruang peribadatan dapat dilihat dari denah gereja. Denah lantai dasar ini berbentuk salib dengan salah satu sisi yang lebih panjang. Berdasarkan teori, sisi yang memiliki perbedaan panjang sisi merupakan denah salib Latin. Bagian denah juga dibagi menjadi tiga bagian yang terdiri atas area depan, tengah, dan belakang.

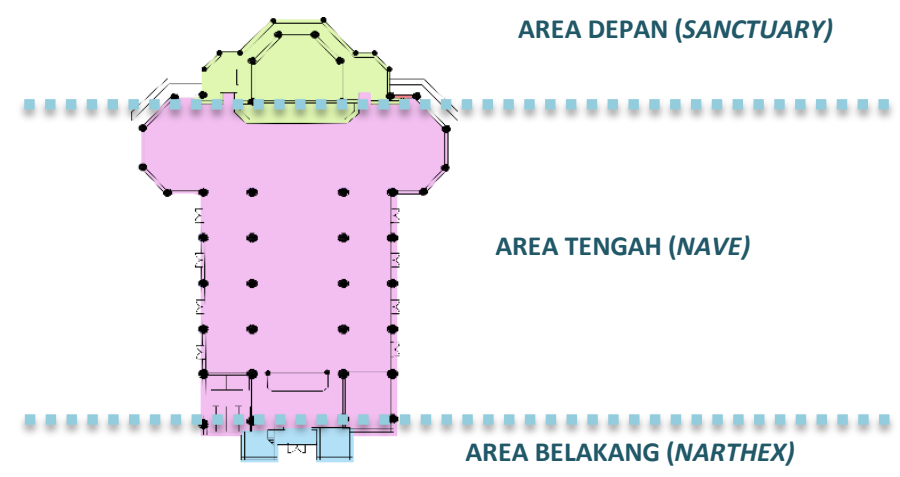

Figur 4. Pembagian denah gereja

Sanctuary merupakan bagian dimana Pastor berdiri. Pada bagian ini juga terdapat ruang bagi Pastor dan Lektor untuk mempersiapkan diri sebelum misa dimulai. Pada bagian tengah gereja digunakan sebagai tempat bagi umat untuk beribadat. Sedangkan bagian belakang (narhex) Gereja adalah sebagai tempat masuk umat, area peralihan antara ruang luar dan ruang dalam. Berikut pembahasan per bagian denah pada gereja.

Bagian depan (sanctuary)

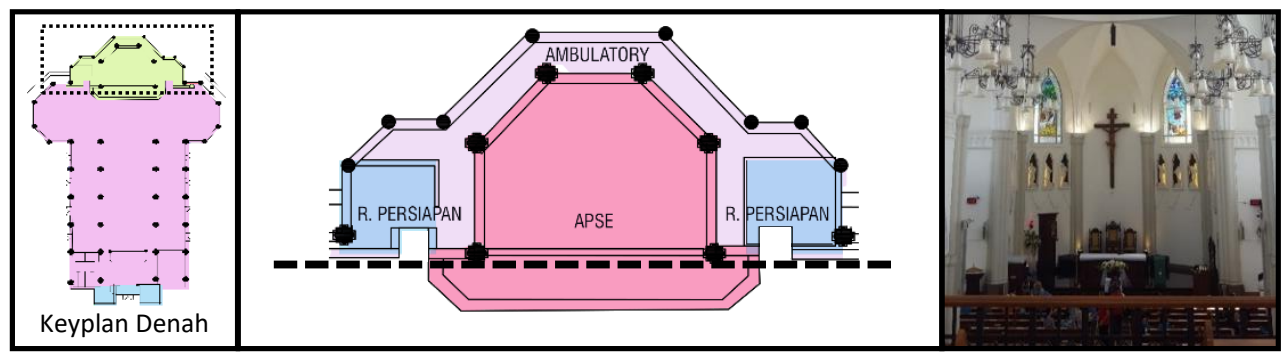

Figur 5. Area Sanctuary

Bagian depan berada di bagian depan yaitu area sekitar altar gereja yang terdiri dari apse, ambulatory, serta ruang persiapan. Apse merupakan area panti imam. Sanctuary sebagai tempat Pastor memimpin tempat peribadahan. Pada bagian ini, terdapat tabernakel. Pada objek studi, apse berbentuk poligonal patah-patah. Pada bagian apse ini terdapat serta ruang persiapan bagi pastor sebelum memimpin peribadatan. Di sekeliling apse, terdapat ambulatory. Bagian Altar ini ditinggikan dengan 4 anak tangga dengan lantai yang bermaterialkan marmer berwarna hitam dengan dimensi 40x40 cm.

(2) Bagian tengah (nave) 

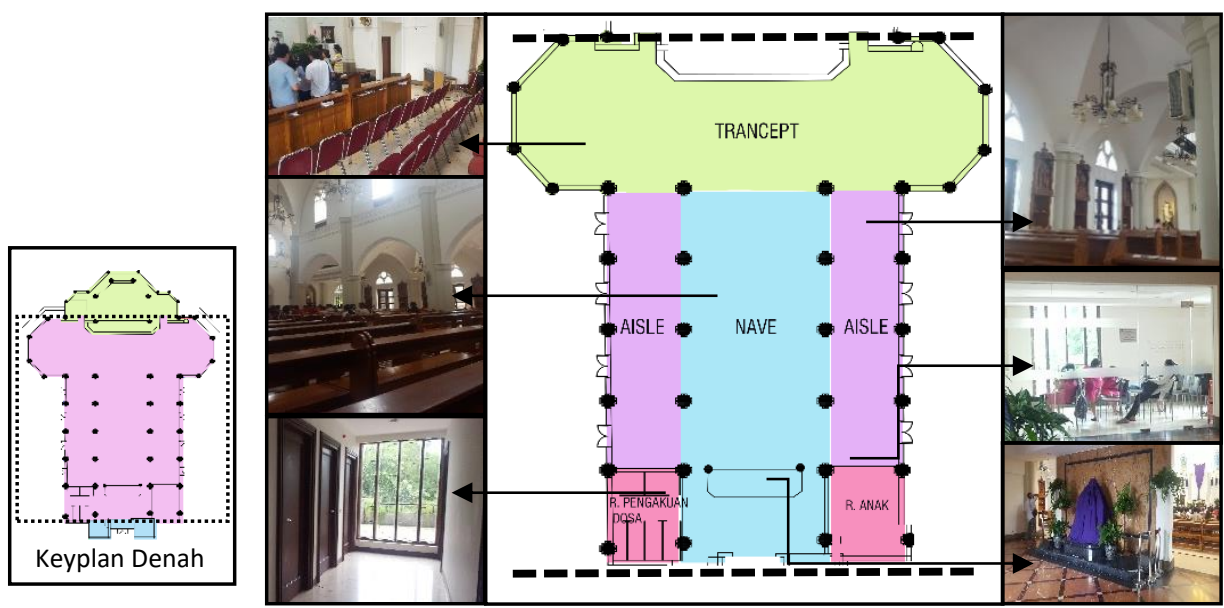

Figur 6. Area Nave

Bagian tengah gereja terdiri dari nave, aisle, trancept, serta apse. Bagian tengah gereja memiliki bentuk yang simetri pada bagian kiri dan kanannya. Area ini menggunakan material lantai marmer berwarna krem dengan dimensi 40x40 cm. Pada bagian sirkulasi tengah yang merupakan sirkulasi utama sebagai pembeda digunakan marmer yang berwarna lebih gelap yaitu warna coklat kemerahan dengan pola membentuk kotak-kotak.

Pada bagian nave terdapat 12 kolom yang melambangkan keduabelas murid Yesus. Di sisi kiri kanan nave terdapat aisle. Aisle ini juga digunakan sebagai tempat duduk umat. Antara aisle dan nave dipisahkan oleh kolom yang berjajar. Pada bagian ujung sisi kiri kanan nave terdapat ruang pengakuan dosa yang merupakan bagian apse pada denah badan gereja. Sedangkan di sebelah kananya terdapat ruang anak dimana umat yang membawa anak-anak dapat menggunakan ruangan ini. Bagian lengan gereja disebut trancept. Pada sisi kanan trancept diguanakan sebagai area paduan suara.

Pada bagian sisi kiri kanan lengan gereja terdapat tangga yang menghubungkannya dengan balkon di atasnya. Tangga ini terbuat dari konstruksi baja dengan penutup lantai kayu yang dilapisi dengan karpet berwarna coklat.

Bagian belakang (narthex)

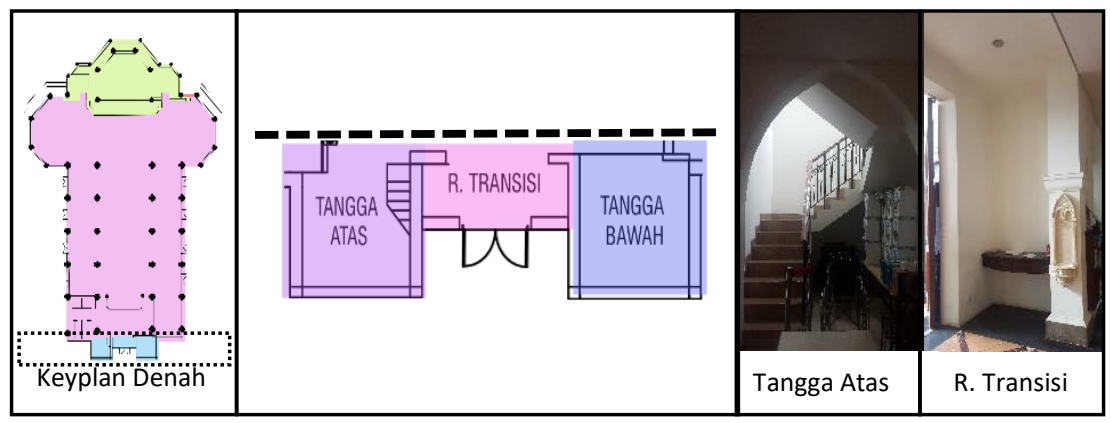

Figur 7. Denah narthex

Bagian belakang gereja (narthex) pada denah terdiri dari serambi, menara, serta atrium. Serambi berupa ruang transisi di depan pintu masuk yang memisahkan antara ruang luar dan ruang dalam. Pada ruang transisi ini juga terdapat tempat air suci. 
Di sisi kiri kanan ruang transisi terdapat tangga menuju atas, yaitu menuju balkon belakang dan tangga menuju ke bawah, yaitu menuju ruang serba guna.

Atrium gereja terdapat di depan pintu masuk. Antara atrium dengan pintu masuk gereja terdapat drop off kendaraan. Atrium ini berupa plaza berbentuk oval dengan luas $930 \mathrm{~m}^{2}$ yang berfungsi untuk menampung umat agar tidak terlalu berdesakan ketika misa selesai.

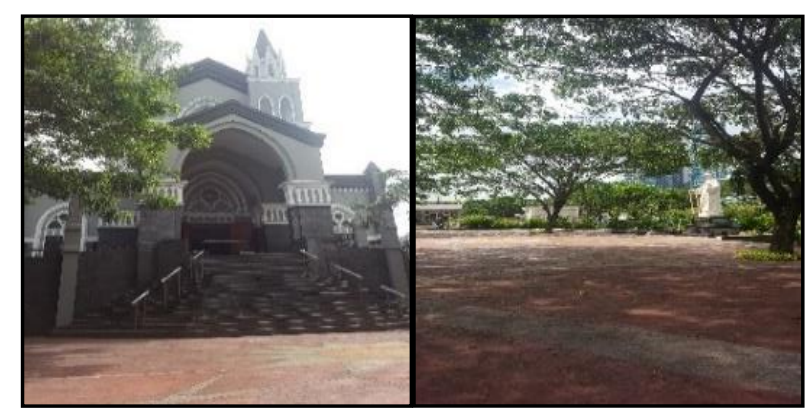

Figur 11. Atrium di denan Gereia

Tabel 9. Kesimpulan Analisa Susunan Ruang

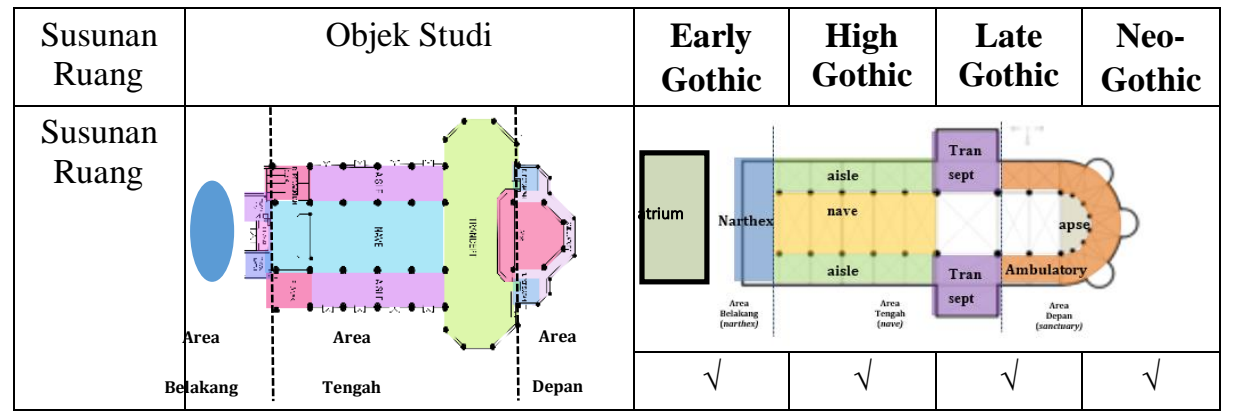

Berdasarkan tabel 9, dapat disimpulkan bahwa susunan ruang pada objek studi menerapkan susunan ruang pada keempat periode Gothic. Berikut merupakan tabel rangkuman hasil analisis elemen bangunan pada Gereja Santo Laurensius berdasakan perkembangannya periode dalam Arsitektur Gothic.

Periode arsitektur yang menerapkan penerapan elemen tersebut akan ditandai dengan tanda ceklis $(\sqrt{ })$.

Tabel 10. Elemen pada Gereja berdasarkan perkembangan periode Gothic

\begin{tabular}{|c|c|l|c|c|c|c|}
\hline \multirow{2}{*}{ NO } & Elemen & $\begin{array}{c}\text { Early } \\
\text { Gothic }\end{array}$ & $\begin{array}{c}\text { High } \\
\text { Gothic }\end{array}$ & $\begin{array}{c}\text { Late } \\
\text { Gothic }\end{array}$ & $\begin{array}{c}\text { Neo- } \\
\text { Gothic }\end{array}$ \\
\hline \multirow{3}{*}{ Kolom } & 1 & Landasan Kolom & - & - & - & $\sqrt{ }$ \\
\cline { 2 - 7 } & 2 & Badan Kolom & - & - & - & $\sqrt{ }$ \\
\cline { 2 - 7 } & 3 & Kepala Kolom & - & - & - & - \\
\hline \multirow{4}{*}{ Pemding } & 4 & Flying Buttress & - & - & - & $\sqrt{ }$ \\
\hline \multirow{2}{*}{ Atap } & 5 & Ribbed Vault & - & - & - & - \\
\cline { 2 - 7 } & 6 & Kubah & - & - & - & - \\
\hline
\end{tabular}




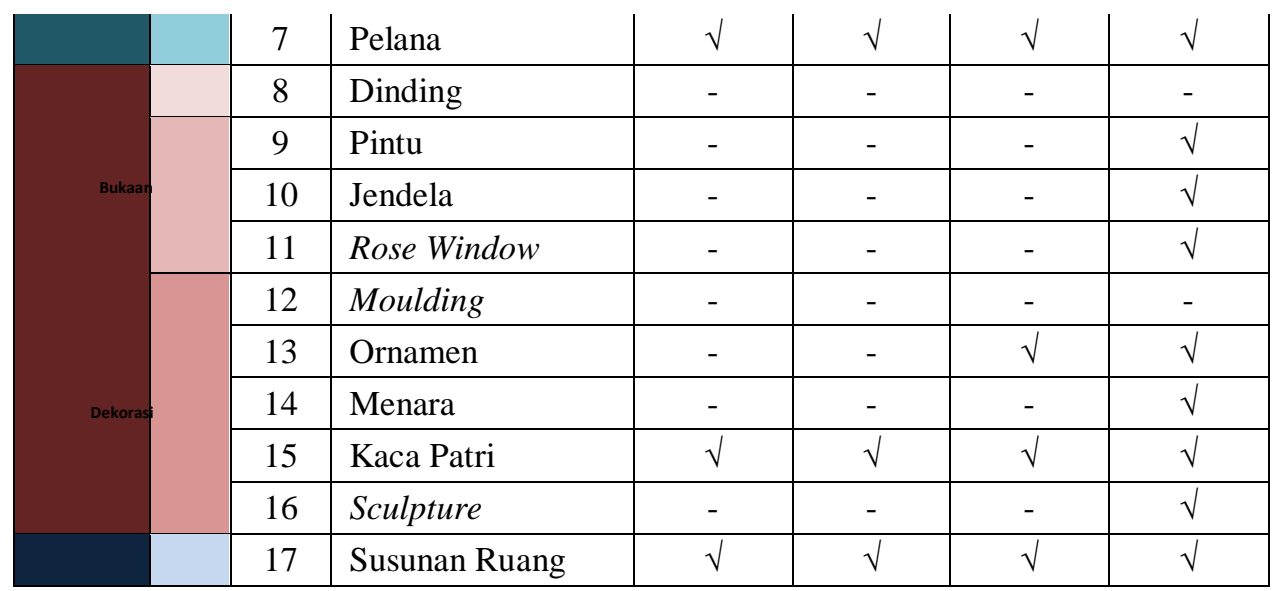

Pada tabel terlihat pembagian elemen arsitektur Gothic yang terbagi ke dalam elemen struktural yang ditandai dengan warna hijau, elemen non-struktural yang ditandai dengan warna merah, serta susunan ruang yang ditandai dengan warna biru.

Elemen struktural terdiri dari landasan kolom, badan kolom, kepala kolom, flying buttress, ribbed vault, kubah, serta pelana. Elemen non-struktural terdiri dari dinding pengisi, pintu, jendela, rose window, moulding, ornamen, menara, kaca patri, serta sculpture. Susunan ruang dilihat dari denahnya.

Berdasarkan hasil analisa ditemukan bahwa sebagian besar penerapan elemen Arsitektur Gothic yang diterapkan pada objek studi diadaptasi dari elemen Arsitektur Gotik yang berasal dari periode Neo-Gothic.

\section{KESIMPULAN}

Berdasarkan pertanyaan penelitian "Bagaimana penerapaan elemen Arsitektur Gothic di Gereja Santo Laurensius Serpong?”, maka dirumuskan kesimpulan yang merupakan hasil dari analisa sebagai berikut.

Dari analisa penerapan elemen Arsitektur Gothic pada Gereja Santo Laurensius ini dapat terlihat bahwa dari 17 unsur yang dianalisa, 12 unsur diantaranya diadaptasi dari elemen bangunan yang terdapat pada periode Arsitektur Neo-Gothic sehingga disimpulkan bahwa penerapan elemen Arsitektur Gothic pada Gereja didominasi oleh Arsitektur Gothic yang berasal dari periode NeoGothic.

5 unsur lain yang tidak menyerupai periode Gothic meliputi bentuk kepala kolom, ribbed vault, kubah, dinding pengisi, serta moulding. Kelima elemen ini memiliki perubahan bentuk baik secara visual maupun sistem penerapannya dalam bangunan dari segi strukturnya.

Pada perbedaan penerapan elemen bangunan yang tidak menyerupai periode Gothic ini terlihat adanya penyesuaian bangunan dengan teknologi dan ilmu pengetahuan yang telah berkembang pada masa kini. Beberapa bagian elemen nampak dibuat lebih sederhana serta melihat juga dari sisi kemudahan pembuatannya sehingga elemen Gothic yang diterapkan tidak lagi murni seperti elemen Gothic pada masanya melainkan telah dibuat penyesuaian berdasarkan perkembangan zaman.

\subsection{TEMUAN}


Elemen Arsitektur Gothic yang diterapkan pada objek studi memiliki beberapa perbedaan dengan elemen Arsitektur Gothic yang terdapat pada masa lalu. Hal ini diduga karena adanya pengaruh perkembangan teknologi dari segi desain maupun segi sistem struktur. Seiring perkembangan zaman dan berkembangnya teknologi, bangunan yang menerapkan unsur Gothic pada elemennya ini membuat suatu inovasi dalam mengupayakan teknologi yang telah berkembang sehingga Gothic yang terdapat pada objek studi merupakan elemen Gothic yang telah mendapat pengaruh ilmu modern dalam penerapannya.

Berdasarkan hal tersebut, ditemukan bahwa bangunan sebagian besar diadaptasi dari elemenelemen yang ada pada periode Neo-Gothic dan dalam penerapannya juga memperhitungkan faktor-faktor kemudahan dalam pembuatannya sehingga digunakan beberapa penerapan yang ada di zaman modern sehingga dapat tercipta bangunan yang estetis dan efisien.

\section{DAFTAR PUSTAKA}

Athena Publications, Inc (2016). Introduction : The Flowering of the Gothic in Northen France. Diakses Maret 2017, dari http://www.athenapub.com/14gothic-sculpture.htm

DeLa Croix, Horst, (1996). Gardner's Art Through The Ages 10th ed. Boston : Watsworth.

Dingley, Andy (2015). Gothic Architecture. Diakses Maret 2017, dari http://www.wikiwand.com/en/Gothic_architecture

Moris, Edd, (2010). The Seven Key Characteristic of Gothic Architecture. Diakses April 2017, dari http://www.exploring-castles.com/castle designs/ characteristics_gothic_architecture8

Parker, John Henry, (1849). Introduction of the Study of Gothic Architecture. Oxford : Shrimpton.

Smith, Thomas Roger, (1880). Architecture, Gothic and Renaisance. London : Bread Street Hill.

Werner, Berthold (2014). Italian Gothic Architecture. Diakses Maret 2017, dari http://www.wikiwand.com/en/Italian_Gothic_Architecture 